\title{
Community structure of lactic acid producing bacteria in the guts of freshwater shrimps
}

\author{
Yan-Ting Zhao ${ }^{1}$, Lin Ye ${ }^{1}$, Cui-Lan Duan ${ }^{2}$, Xu-Xiang Zhang ${ }^{1 *}$ \\ ${ }^{1}$ State Key Laboratory of Pollution Control and Resource Reuse, School of the Environment, Nanjing University, Nanjing 210023, P.R. \\ China \\ ${ }^{2}$ Fisheries Technology Extension Center of Jiangsu Province, Nanjing 210036, P.R. China
}

\begin{abstract}
The lactic acid producing bacteria (LAB) play a crucial role in the health of aquatic animals through controlling and competing against pathogens. In this study, based on the high-throughput sequencing of 16S rRNA gene amplicons, we examined the LAB in the gut of freshwater shrimps (Macrobrachium nipponense) and their living environments (sediment and pond water) and analyzed the correlations between the shrimp production and abundance of LAB. A high diversity and abundance of LAB (27 genera) were observed among the freshwater shrimp gut samples, and the results indicated that dissolved oxygen and temperature could affect the LAB community in the shrimp guts. In addition, shared and unique LAB among the shrimp guts, sediment and pond water were further analyzed. Linear regression analysis showed that the relative abundance of LAB was positively correlated with the levels of shrimp production. Moreover, comparison of the LAB community among different animals indicated that some LAB in shrimp guts may also play a beneficial role in fish, houseflies, pig and other animals. Collectively, this study provides comprehensive information for better understanding LAB in shrimp guts and their environments and further improving the ecological management of aquatic ecosystems regarding the application of probiotics and disease prevention.
\end{abstract}

Keywords: lactic acid bacteria, microbial community, freshwater shrimps, 16S rRNA gene

* Correspondence to: Xu-Xiang Zhang, State Key Laboratory of Pollution Control and Resource Reuse, School of the Environment, Nanjing University, Nanjing 210023, China; E-mail: zhangxx@nju.edu.cn

Received: April 17, 2018; Accepted: May 18, 2018; Published Online: May 25, 2018

Citation: Yan-Ting Zhao, Lin Ye, Cui-Lan Duan, Xu-Xiang Zhang, 2018. Community structure of lactic acid bacteria in the freshwater shrimps. http://doi.org/10.26789/AEB.2018.02.001.

Copyright: Community structure of lactic acid producing bacteria in the freshwater shrimps.C 2018 Yan-Ting Zhao et al.. This is an Open Access article distributed under the terms of the Creative Commons Attribution-Noncommercial 4.0 International License, permitting all non-commercial use, distribution, and reproduction in any medium, provided the original work is properly cited and acknowledged.

\section{Introduction}

Lactic acid bacteria (LAB) are a group of Gram-positive, usually nonmotile, nonsporulating, rod or coccus-shaped organisms that produce lactic acid as their major or sole end product during the fermentation of carbohydrates (Ringo et al., 1998; Von Wright, 2012). These bacteria are widespread in natural environments, such as oral cavity (Gungor et al., 2013), skin (Jeong et al., 2016), the gastrointestinal tract of various animals (Stolaki et al., 2012), milk and dairy products (Lee et al., 2013), seafood products (Ghanbari et al., 2013), meat (Egan, 1983) and so on. In recent years, $\mathrm{LAB}$ are have attracted growing attention because of their potential usage as safe additives for preservation of food products (Pothakos et al., 2014) and other applications such as treatment of pathogenic diseases, cancer prevention and immunity enhancement (Rajoka et al., 2017; Matsumoto et al., 2009).

Aquaculture has been regarded as a fast-growing industry and has been rapidly developed with the advance of cultivation methods. However, the increasing occurrence of various diseases has become a significant limiting factor of the commercial aquaculture (Bachere, 2000). Probiotics have been shown to have an important role alternative to chemicals and antibiotics in aquaculture (Yu et al., 2005). Potential probiotics could be obtained from various sources such as the gastrointestinal tracts, mucus of aquatic animals (Newaj-Fyzul et al., 2007; Tapia-Paniagua et al., 2012), commercial products (Suzer et al., 2008) or isolated from the aquatic environments such as water or sediment (Van Hai et al., 2007). As candidate probiotics, LAB have been widely used in aquaculture toimprove fish health. For instance, some attempts have been made to increase the abundance of Carnobacterium and Lactobacillus in the gastrointestinal tract of fish (Ringo et al, 1998). In addition, some LAB isolated from fish digestive tract were considered as allochthonous probiotics, and used as potential probiotic bacteria to enhance immune system by colonizing the intestine of rainbow trout (Nikoskelainen et al., 2003).

As one of the most important commercial aquatic animals, freshwater shrimp is widely cultured in Asia and other countries around the world (Rahman et al., 2016). 
Pair-wise comparisons were performed in oriental river prawns and indicated that probiotics (such as Lactobacillus, Streptococcus) were the core microbiota, and predicted that these bacteria may play functional roles in the immune and digestion systems in shrimp gut (Tzeng et al., 2015). Although this study provided important clues about the probiotics in freshwater shrimps, the detailed information of LAB in freshwater shrimps and their living environment still remain unknown. For example, how about the diversity and abundance of LAB in shrimp gut, pond water and sediment? How do environmental factors affect the LAB in shrimp gut? How about the relationship between the shrimp production and the LAB community? Answering these questions may improve our understanding of the use of probioticsin freshwater shrimp farming.

In this study, high-throughput sequencing of the $16 \mathrm{~S}$ rRNA gene was applied to characterize LAB diversity and abundance in the gut of Macrobrachium nipponensis and their living environments (sediment and pond water). Our results revealed high diversity of LAB in the gut of freshwater shrimp its association with the LAB in sediment and pond water. We also analyzed the shared and unique LAB among the shrimp gut, sediment and pond water,and evaluated relationships between LAB and environmental factors. Moreover,the possible correlation between the shrimp production and abundance of LAB was also revealed.

\section{Materials and methods}

\subsection{Sample Sites and Sample Collection}

Shrimp samples ( $M$. nipponense) were obtained from 25 shrimp ponds at five different shrimp farms (LY, SZ, $\mathrm{WX}, \mathrm{XH}$ and YZ) in Jiangsu, China between March and September of 2016. Sediment and pond water from each shrimp pond were also collected. At each farm, 20 shrimps were collected from three different ponds and transported to the laboratory within 4 hours for dissection. One liter of pond water sample was collected from the center of each pond at a depth of $10 \mathrm{~cm}$, and five sediment samples were collected from each shrimp pond (one from the center and the other four from the four corners of each pond) and transferred to sterile polyethylene bottles. Sediment samples from one pond were mixed well to form a single sample (approximately $200 \mathrm{~g}$ ). After dissection, the gut contents of the shrimps from each pond collected at each sampling time were pooled for DNA extraction. For pond water, $200 \mathrm{ml}$ of each sample was filtered through a $0.45 \mu \mathrm{m}$-pore size membrane to collect bacteria. After pretreatment, all of the samples (shrimp gut contents, membrane filtrates and sediments) were collected and stored at $-80{ }^{\circ} \mathrm{C}$ until DNA extraction.

Total organic carbon (TOC), total nitrogen (TN) and total phosphorus (TP) in the pond water were analyzed according to the standard methods (APHA, 2012). Water temperature,
$\mathrm{pH}$ and dissolved oxygen (DO) were measured with portable meters (Table 1).

Table 1. Information of the shrimp samples and detected water quality parameters ( $\mathrm{pH}, \mathrm{T}, \mathrm{DO}, \mathrm{TN}, \mathrm{TP}, \mathrm{TOC})$. Sampling was performed at different sites separately in March, April, May, June, July and September.

\begin{tabular}{|c|c|c|c|c|c|c|c|c|}
\hline $\begin{array}{l}\text { Shrimp } \\
\text { sample }\end{array}$ & site & $\begin{array}{c}\text { Sampling } \\
\text { time }\end{array}$ & $\mathrm{pH}$ & $\begin{array}{l}\text { Temperature } \\
\text { (T) }\end{array}$ & $\begin{array}{c}\text { Dissolved } \\
\text { oxygen } \\
\text { (DO) }\end{array}$ & $\begin{array}{c}\text { Total } \\
\text { nitrogen } \\
122]\end{array}$ & $\begin{array}{c}\text { Total } \\
\text { phosphorus } \\
\text { (TP) }\end{array}$ & $\begin{array}{c}\text { Total } \\
\text { organic } \\
\text { carbon } \\
\text { (TOC) }\end{array}$ \\
\hline S1 & LY & April & 7.94 & 21.34 & 7.81 & 3.44 & 0.11 & 21.57 \\
\hline S2 & LY & April & 8.56 & 22.10 & 7.92 & 1.86 & 0.20 & 15.37 \\
\hline s3 & LY & April & 8.37 & 21.49 & 8.01 & 2.10 & 0.10 & 12.35 \\
\hline S4 & PK & June & 7.31 & 20.52 & 2.29 & 0.56 & 0.79 & 13.45 \\
\hline s5 & PK & June & 7.50 & 19.94 & 4.01 & 0.40 & 0.98 & 16.71 \\
\hline S6 & PK & June & 7.75 & 20.26 & 4.05 & 0.59 & 0.82 & 17.13 \\
\hline S7 & LY & March & 5.08 & 14.37 & 7.64 & 0.33 & 3.06 & 18.62 \\
\hline s8 & LY & March & 8.58 & 16.89 & 7.71 & 0.13 & 1.56 & 11.52 \\
\hline s9 & LY & March & 8.58 & 16.89 & 7.71 & 0.12 & 1.56 & 11.52 \\
\hline $\mathrm{s} 10$ & LY & March & 8.52 & 15.72 & 8.29 & 0.19 & 1.97 & 14.96 \\
\hline S11 & LY & September & 7.11 & 23.66 & 7.11 & 0.65 & 2.31 & 19.71 \\
\hline $\mathrm{S} 12$ & LY & September & 8.28 & 26.04 & 4.97 & 0.60 & 1.98 & 19.10 \\
\hline $\mathrm{S} 13$ & LY & September & 8.55 & 25.15 & 5.03 & 0.49 & 1.76 & 23.40 \\
\hline S14 & $\mathrm{YZ}$ & September & 8.12 & 24.67 & 8.31 & 1.03 & 0.05 & 11.43 \\
\hline S15 & $\mathrm{YZ}$ & September & 8.31 & 23.94 & 7.87 & 1.12 & 0.11 & 16.12 \\
\hline $\mathrm{s} 16$ & $\mathrm{YZ}$ & September & 7.54 & 25.85 & 7.09 & 1.39 & 0.09 & 13.42 \\
\hline S17 & $\mathrm{YZ}$ & April & 9.04 & 19.82 & 4.52 & 0.51 & 0.06 & 16.64 \\
\hline $\mathrm{s} 18$ & $\mathrm{YZ}$ & April & 7.97 & 20.84 & 5.00 & 0.45 & 0.03 & 13.37 \\
\hline $\mathrm{S} 19$ & $\mathrm{YZ}$ & April & 8.51 & 18.72 & 4.29 & 0.59 & 0.07 & 14.96 \\
\hline $\mathrm{s} 20$ & wX & April & 8.04 & 20.17 & 6.36 & 1.06 & 0.14 & 23.82 \\
\hline S21 & wx & April & 8.56 & 20.58 & 7.63 & 1.02 & 0.09 & 53.32 \\
\hline $\mathrm{S} 22$ & wx & April & 8.37 & 21.49 & 8.01 & 2.10 & 0.10 & 32.35 \\
\hline S23 & LY & April & 8.56 & 22.1 & 7.92 & 1.86 & 0.20 & 15.37 \\
\hline S24 & LY & April & 8.37 & 21.49 & 8.01 & 2.10 & 0.10 & 12.35 \\
\hline S25 & LY & May & 8.21 & 18.54 & 5.42 & 0.02 & 1.88 & 22.36 \\
\hline $\mathrm{S} 26$ & LY & May & 8.31 & 21.86 & 5.20 & 0.05 & 1.18 & 13.09 \\
\hline S27 & LY & May & 8.21 & 18.54 & 5.42 & 0.02 & 1.88 & 22.36 \\
\hline S28 & LY & May & 8.58 & 17.03 & 5.46 & 0.02 & 0.89 & 12.62 \\
\hline S29 & PK & June & 7.64 & 20.16 & 2.25 & 0.43 & 0.87 & 13.73 \\
\hline $\mathrm{S} 30$ & PK & June & 7.53 & 20.24 & 3.11 & 0.47 & 0.82 & 19.41 \\
\hline S31 & PK & June & 7.59 & 20.20 & 4.03 & 0.39 & 0.80 & 16.34 \\
\hline S32 & $\mathrm{YZ}$ & July & 8.37 & 30.66 & 6.86 & 1.10 & 1.21 & 23.42 \\
\hline S33 & $\mathrm{YZ}$ & July & 8.49 & 30.50 & 7.32 & 0.76 & 1.09 & 20.13 \\
\hline $\mathrm{S} 34$ & $\mathrm{YZ}$ & July & 7.79 & 30.54 & 5.17 & 0.61 & 0.98 & 18.79 \\
\hline \$35 & $\mathrm{YZ}$ & July & 7.11 & 29.37 & 7.11 & 0.97 & 0.95 & 16.31 \\
\hline $\mathrm{S} 36$ & $\mathrm{YZ}$ & July & 8.28 & 28.89 & 4.97 & 2.01 & 1.30 & 18.91 \\
\hline S37 & sz & April & 7.97 & 23.00 & 8.02 & 2.80 & 0.03 & 32.37 \\
\hline S38 & sz & April & 7.89 & 23.28 & 7.93 & 1.37 & 0.05 & 29.79 \\
\hline \$39 & $\mathrm{XH}$ & April & 7.48 & 20.01 & 2.81 & 4.30 & 0.07 & 28.79 \\
\hline$\$ 40$ & $\mathrm{XH}$ & April & 7.33 & 21.86 & 3.12 & 4.00 & 0.06 & 26.98 \\
\hline
\end{tabular}

\subsection{DNA Extraction, PCR and Bacterial 16S rRNA Gene Sequencing}

DNA was extracted from the sediment, gut contents and pond water samples using the Fast DNA SPIN Kit for Soil (MP Biomedicals, CA, USA). The concentration and quality of the extracted DNA were checked using a NanoDrop 2000 (NanoDrop Technologies, Willmington, DE, USA) and agarose gel electrophoresis. V3-V4 hypervariable regions of the 16S rRNA gene was amplified by universal bacterial primers 341F (5'-CCT ACG GGN GGC WGC AG-3') and 806R (5'-GGA CTA CHV GGG TWT CTA AT-3'). The PCR amplification was conducted in a reaction system (30 $\mu \mathrm{L})$ containing $5 \mu \mathrm{L}$ of template DNA $(50 \mathrm{ng} / \mu \mathrm{L}), 2.5 \mu \mathrm{L}$ of the forward primer, $2.5 \mu \mathrm{L}$ of the reverse primer, $5 \mu \mathrm{L}$ of dd $\mathrm{H}_{2} \mathrm{O}$, and $15 \mu \mathrm{L}$ of $2 \times$ Phusion $®$ High-Fidelity PCR Master Mix with GC Buffer (TransGen Biotech, China). The PCR condition was as follows: $95^{\circ} \mathrm{C}$ for $2 \mathrm{~min}$, followed by 30 cycles of $95{ }^{\circ} \mathrm{C}$ for $20 \mathrm{~s}, 51{ }^{\circ} \mathrm{C}$ for $30 \mathrm{~s}, 72{ }^{\circ} \mathrm{C}$ for $60 \mathrm{~s}$, and a final elongation step at $72{ }^{\circ} \mathrm{C}$ for $5 \mathrm{~min}$. The PCR products were purified with a QIAquick PCR Purification Kit (QIAGEN) and quantified on a Qubit 2.0 Fluorometer (Invitrogen). 
The purified PCR products were sent to Jiangsu Zhongyijinda Analytical \& Testing Co., Ltd. for library preparation and high-throughput sequencing on a Miseq sequencer (Illumina, San Diego, CA, USA). The sequencing data have been submitted to Sequence Read Archive database in NCBI under accession number PRJNA381860.

\subsection{Sequencing data analysis and LAB iden- tification}

After sequencing, the paired-end reads were joined using Mothur (Schloss, 2009), and potential chimeric sequences introduced in the PCR process were then detected and removed using "chimera.uchime" in Mothur. The high-quality reads were subsequently clustered into operational taxonomic units (OTUs) at a similarity of 0.97 using the Quantitative Insights into Microbial Ecology (QIIME) pipeline (Caporaso, 2010). Low-abundance OTUs (<three reads) were regarded as sequencing noise and removed from further analysis. The taxonomy of the representative sequence of each OTU was assigned with the RDP Classifier (Wang et al., 2007). The OTUs affiliated with the following genera Lactococcus, Atopostipes, Eremococcus, Lactovum, Lactobacillus, Lacticigenium, Globicatella, Atopobacter, Carnobacterium, Pilibacter, Melissococcus, Enterococcus, Trichococcus, Streptococcus, Vagococcus, Abiotrophia, Weissella, Pediococcus, Alloiococcus, Bavariicoccus, Dolosigranulum, Desemzia, Facklamia, Aerococcus, Isobaculum, Dolosicoccus and Paralactobacillus were identified as LAB according to the previous studies (Ringo et al., 1998; Ringo et al., 2010; Maeda et al., 2014).

\subsection{Statistical analysis}

Non-metric multidimensional scaling (NMDS) was performed to evaluate the differences in LAB among the different samples based on the relative abundance. The correlation between the LAB and water parameters were examined using redundancy analysis (RDA) based on the dominant genera. NMDS and RDA were performed using the "vegan" package in $\mathrm{R}$ (version 3.2.3). Heatmap was also performed in R (Version 3.2.3) with the "gplots" packages. The association and linear regression analysis between the total abundance of the LAB and shrimp production was performed using ORIGIN 8.0.

\section{Results and Discussion}

\subsection{LAB in shrimp gut, sediment and pond water}

In this study, a high diversity of LAB (27 genera) was observed in the shrimp guts, sediment and pond water. Fig. 1 illustrates the relative abundance of the LAB that were commonly observed in the three kinds of samples. In general, the community of LAB in the shrimp gut samples showed a higher level of diversity and abundance than those in the sediment and pond water samples. The most dominant genus in the shrimp gut was Lactococcus $(2.23 \pm 5.26 \%)$, followed by Lactovum $(0.90 \pm 2.88 \%)$ and Atopostipes $(1.54 \pm 2.46 \%)$. However, it was also found that the LAB community in the pond water and sediment differed from the shrimp gut at different sampling times. In total 18 genera of LAB were observed in the sediment samples and the three most abundant genera were Lactobacillus (1.03\%), Atopostipes (0.71\%) and Lactococcus $(0.15 \%) .16$ genera of LAB, including Atopostipes (1.15\%), Lactobacillus (0.37\%), Lactococcus $(0.30 \%)$, etc., were observed in the pond water samples.

\subsection{Share and Unique LAB among the shrimp gut, sediment and pond water}

An NMDS plot (Fig. 2) based on the relative abundance of LAB was created to compare the similarity of the microbial community composition in different samples. As expected, the three kinds of samples (shrimp guts, pond water and sediment) were clearly separated and formed three distinct groups, suggesting that the LAB communities in these samples were obviously different. However, it was also found that some $\mathrm{LAB}$ were present in all of the three kinds of samples. The shared and unique LAB were further analyzed. As shown in Fig. 3, high diversity of unique LAB was observed in the shrimp gut, indicating that shrimp gut is a major reservoir of LAB. Seven shared LAB were observed among the three kinds of samples and they represented 60.98 $\pm 28.65 \%, 72.90 \pm 39.95 \%$ and $69.71 \pm 31.46 \%$ of the total LAB abundances in the shrimp gut, water and sediment samples, respectively. The two shared genera between the shrimp gut and water samples accounted for $55.28 \pm 7.29 \%$ and $7.89 \pm 21.08 \%$ of their total LAB abundances, respectively. And, three genera were shared between the gut and sediment samples, accounting for $35.58 \pm 27.23 \%$ of the gut LAB and $19.69 \pm 29.09 \%$ of the sediment LAB. However, Aerococcus and Dolosigranulum genera were only found in sediment, and no shared genera between the water and sediment samples were observed. These results demonstrated that LAB in shrimp guts have certain similarities with those in sediment and pond water, which indicates that LAB in sediment and pond water may affect the LAB community in shrimp guts.

\subsection{Relationships between LAB and environ- mental factors}

RDA was used to investigate the relationship between LAB communities in three kinds of samples and environmental factors, including water temperature, $\mathrm{pH}, \mathrm{TP}, \mathrm{DO}, \mathrm{TOC}$ and TN. As shown in Fig. 4, two factors, DO and temperature (T), were found to significantly contribute to the relationship between LAB community and environmental factors. Many LAB genera, such as Aerococcus, Dolosigranulum, Vagococcus and Trichococcus, were positively correlated with temperature. It is widely accepted that temperature is an important factor shaping bacterial community structure in natural environments (Staley et al. 2015); however, its ef- 


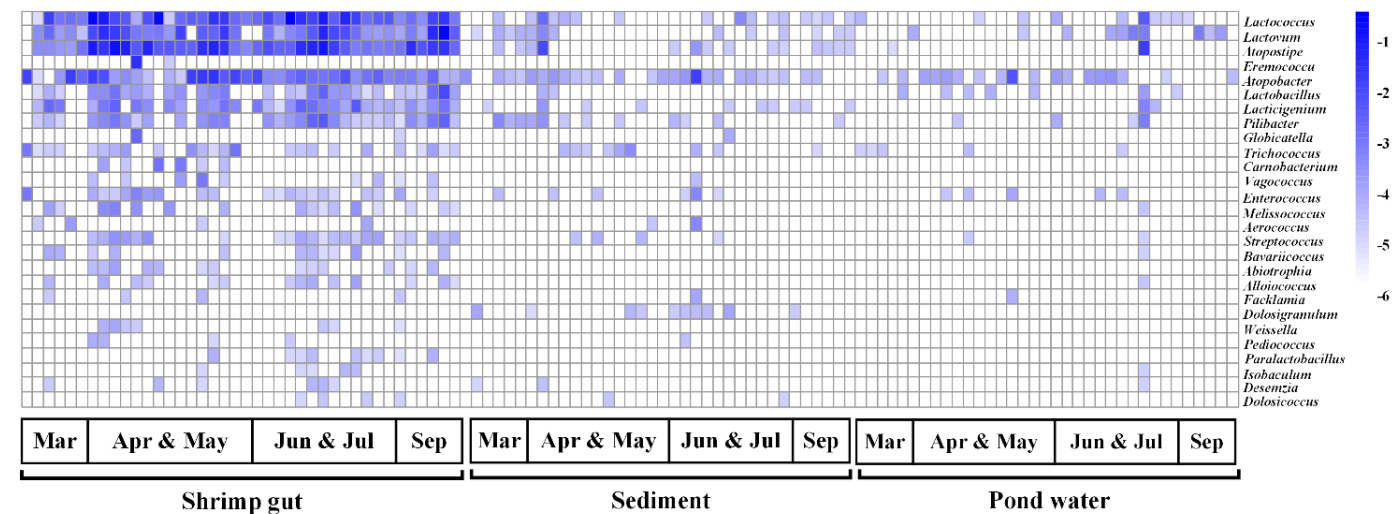

Figure 1. LAB in shrimp guts and the surrounding environment (water and sediment) at different sampling times.

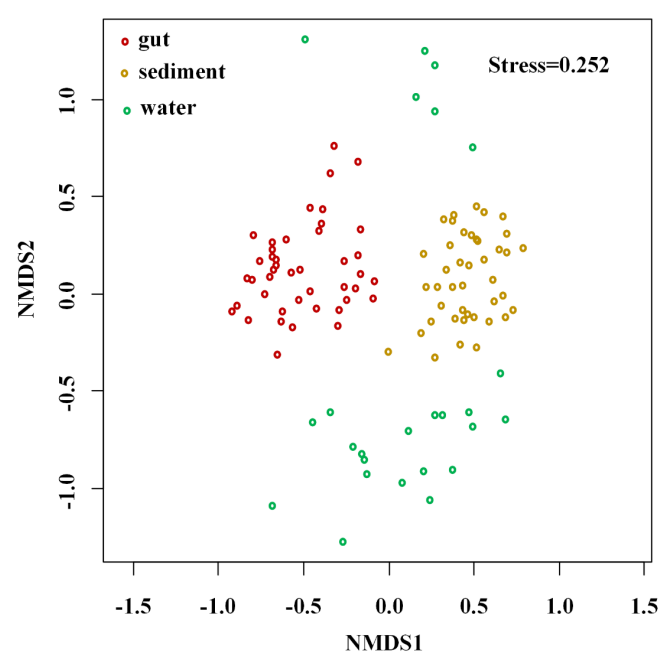

Figure 2. NMDS plot showing the LAB composition differences among the three environmental samples. fects on the LAB in aquaculture environments have seldom been reported. Carnobacterium was the only genus strongly correlated with TP.

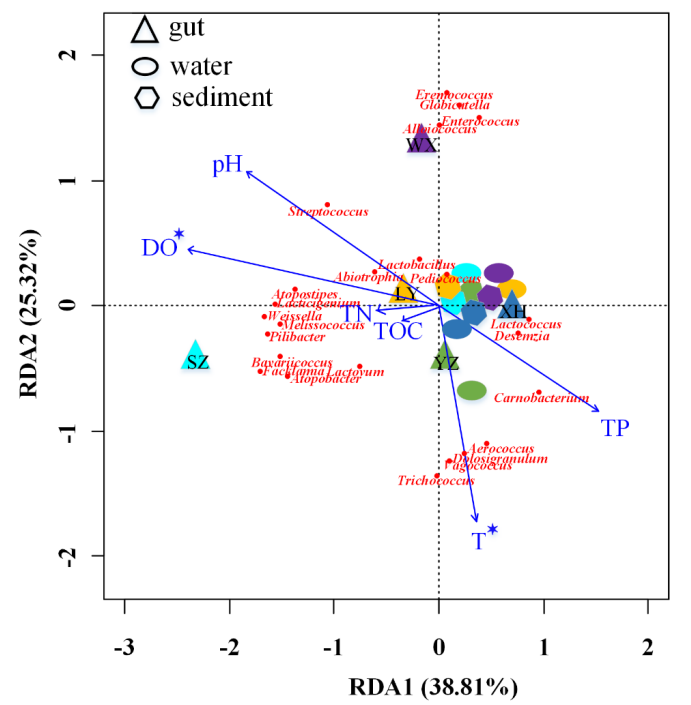

Figure 4. Redundancy analysis illustrating the relationships of the water quality parameters (TP, TOC, TN, T, DO, and $\mathrm{pH}$ ) (arrows) with the abundance of the major LAB in different samples. Different colors of the symbols indicate different sampling sites.

\subsection{Correlations between the shrimp produc- tion and abundance of LAB}

In this study, we also investigated the relationship between the shrimp production and abundance of LAB in shrimp gut. Fig. 5 shows that the relative abundance of LAB was positively correlated with shrimp production $\left(r^{2}=0.89\right)$. To the best of our knowledge, this is the first study to quantitatively demonstrate the correlations between the shrimp production and the abundance of LAB, although many studies have reported that $\mathrm{LAB}$ and their metabolic products as potential probiotics may have effects on the survival, immune response, growth performance and yield of animals. For instance, the strain Lactococcus lactis D1813, isolated from Kuruma Shrimp (Marsupenaeus japonicus) intestine, could significantly increase the resistance to the bacterial 


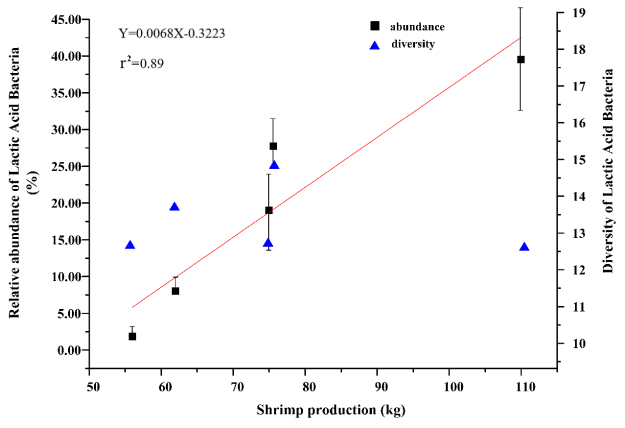

Figure 5. Correlations between therelative abundance of LAB and the corresponding shrimp production in different sampling sites by linear regression analysis.

pathogen in term of better post-infection survival (Maeda et al., 2014). Streptococcus phocae PI80 could enhance the immune ability of Penaeus monodon and increase the shrimp production while it was in the pond water and feed (Pattukumar et al., 2014). Enterococcus faecium MC13, isolated from fish intestine, could abundantly secrete bacteriocin, a synthetic peptide/protein displaying a broad spectrum of antimicrobial activity against pathogenic bacteria (Kanmani, 2011). In addition, Hai systemically reviewed the previous studies and revealed that LAB and Bacillus spp., as probiotics, can control and compete with pathogenic bacteria as well as to promote the growth of the cultured organisms in order to increase production yield in shrimp aquaculture (Hai, 2015). However, another study exploring the effects of commercial microbial products as probiotics on production performance and water quality indicated that no significant differences were found in fish yield and mussel yield even declined (Zheng et al., 2017). Therefore, further research on the effects of LAB on pathogens and the yield production of shrimp is necessary to better understand roles of LAB in aquaculture.

\subsection{Comparing the diversity of LAB in other animal gut}

In this study, we identified 22 LAB genera with high abundance from freshwater shrimp gut. Researchers have also reported that LAB are widely present in other animals. Twenty LAB Amina were isolated from the gastrointestinal tractof Atlantic salmon (Staley et al. 2015), and fifty-one LAB strains, which could be classified into 14 species based on 16S rDNA sequence, were isolated from kuruma shrimp intestine (Maeda et al., 2014). To compare the LAB communities in shrimp gut with those in other animals, Table 2 was summarized from previous studies.

The common dominant LAB presenting within shrimps and other animals are Lactococcus, Lactobacillus, Atopostipes, Trichococcus, Vagococcus, Streptococcus Globicatella, etc. For example, our study revealed that Lactococcus and Lactobacillus are two most dominant LAB genera, accounting for $2.29 \%$ and $0.31 \%$ of the total bacterial population on average, respectively. Other studies
Table 2. A summary of the diversity and character of LAB in other studies.

\begin{tabular}{|c|c|c|c|}
\hline LAB & $\begin{array}{l}\text { Abundance } \\
\text { in this study }\end{array}$ & Host (Ref.) & Function \\
\hline Lactococcus & $2.285 \%$ & $\begin{array}{l}\text { Human }{ }^{[37]} \text {, chicken }{ }^{[38]} \text {, } \\
\text { fish }^{[39]}\end{array}$ & $\begin{array}{l}\text { Enhance the expression of } \\
\text { cytokine,phagocytic activity, and } \\
\text { lysozyme activity }\end{array}$ \\
\hline Atopostipes & $1.544 \%$ & pig ${ }^{[34]}$, fish $^{[40]}$ & $\begin{array}{l}\text { Metabolize valine and tryptophan to } \\
\text { BCFA and indole }\end{array}$ \\
\hline Lactovum & $0.896 \%$ & Not Found & \\
\hline Lactobacillus & $0.307 \%$ & $\begin{array}{l}\text { human }{ }^{[41]} \text {, mice }{ }^{[33]}, \\
\text { fish }^{[1]}\end{array}$ & $\begin{array}{l}\text { Enhance the expression of cytokine, } \\
\text { phagocytic activity, and lysozyme activity }\end{array}$ \\
\hline Eremococcus & $0.066 \%$ & Not Found & \\
\hline Atopobacter & $0.036 \%$ & Not Found & \\
\hline Lacticigenium & $0.047 \%$ & Not Found & \\
\hline Pilibacter & $0.030 \%$ & termite ${ }^{[42]}$ & Not mentioned \\
\hline Globicatella & $0.004 \%$ & piglets ${ }^{[43]}$, fish ${ }^{[44]}$ & Cause meningitis or bacteremiain humans \\
\hline Trichococcus & $0.006 \%$ & penguin ${ }^{[35]}$ & $\begin{array}{l}\text { Grow with citrate, 1-malate, allantoin and } \\
\text { 1-tartrate, and produce acid from mannitol. }\end{array}$ \\
\hline Carnobacterium & $0.004 \%$ & pigs ${ }^{[45]}$, fish $^{[1]}$ & Pathogenic lactic acid bacteria \\
\hline Vagococcus & $0.003 \%$ & houseflies ${ }^{[46]}$, fish ${ }^{[1]}$ & $\begin{array}{l}\text { Produce acid from glycerol, maltose, } \\
\text { ribose, trehalose and methyl } \\
\text { a-D-glucopyranoside }\end{array}$ \\
\hline Enterococcus & $0.005 \%$ & $\begin{array}{l}\text { human }{ }^{[47]}, \text { animal }{ }^{[48]} \text {, } \\
\text { fish }^{[1]}\end{array}$ & Pathogenic lactic acid bacteria \\
\hline Melissococcus & $0.004 \%$ & honeybees ${ }^{[49]}$ & Not mentioned \\
\hline Streptococcus & $0.004 \%$ & wolf $^{[50]}$, fish $^{[51]}$ & $\begin{array}{l}\text { Increase in diets withstarch that have high } \\
\text { amylose/amylopectin ratios andalginate } \\
\text { supplemented diets }\end{array}$ \\
\hline
\end{tabular}

also reported that some bacterial species of Lactococcus and Lactobacillus are commonly found in human, chicken and fish, and Vazquez et al. (2017) isolated Lactococcus lactis from human gastrointestinal tract and explored the effect of soy isoflavones on growth of this bacterial species. Besides, previous studies showed that Lactococcus and Lactobacillus have the function of enhancing the expression of cytokine, phagocytic activity and lysozyme activity (Hai, 2015; Lavari et al., 2017) Atopostipes, another LAB genus ( $1.544 \%$ averagely) in shrimp gut, also constitute a part of the gut microbiota of several pig and fish species. Another study indicated that Atopostipes not only metabolize valine and tryptophan to branched chain fatty acid and indole, but also have strong positive correlation with phenol in volatile organic compounds from chicken litter (Cho et al., 2015). Trichococcus, accounted for $0.006 \%$ of in shrimp gut, was alsoisolated from penguin by Pikuta et al. (Pikuta et al., 2006) and it was reported this bacteria could grow with citrate, 1-malate, allantoin and 1-tartrate, and produce acid from mannitol. Streptococcus was observed in this study, and a previous study indicatedthat species in this genus could influenced by host diet changes, increasing in diets with starch that have high amylose/amylopectin ratios and alginate supplemented diets (Gorham et al., 2017).

However, some LAB in shrimp guts, such as Lactovum, Eremococcus, Atopobacter and Lacticigenium, were seldom 
found in other animal guts, suggesting that they may be unique to shrimp guts and may play significant roles for the growth of shrimps. In addition, some species of Globicatella, Carnobacterium and Enterococcus in the shrimp gut could be potential pathogenic LAB and may cause meningitis or bacteremia in humans. This differences between shrimps and other animals are likely driven by the different physiology of different hosts and selectivity of their diverse living environments.

\section{Conclusions}

The present study comprehensively investigated LAB compositions in the guts of shrimps and their living environment. In total, 27 genera were detected in shrimp gut, pond water and sediment samples. Correlation analysis between LAB and environmental factors indicated that DO and temperature were significantly correlated with the community of the LAB. Linear regression analysis showed that the relative abundance of LAB was positively correlated with the shrimp production $\left(\mathrm{r}^{2}=0.89\right)$. Moreover, NMDS showed higher dissimilarity among the LAB of the three different samples, and only two shared LAB genera were present in the three different samples. Further comparison with other animals revealed that some LAB in shrimps were also present in fish, houseflies, pigs and other animals. Future research may be conducted to isolate LAB from shrimp gut and its environments to develop probiotics and provide information for establishing sustainable microbial management strategies for shrimp farming.

\section{Conflict of Interest and Funding}

No conflict of interest was reported by the authors. This work was supported by the Jiangsu Agriculture Science and Technology Innovation Fund (CX(15)1012), and the Natural Science Foundation for Distinguished Young Scholars of Jiangsu Province of China (BK20150019).

\section{References}

Amin, M., Adams, M., Bolch, C.J.S., and Burke, C.M., 2017. In vitro screening of lactic acid bacteria isolated from gastrointestinal tract of Atlantic Salmon (Salmo salar) as probiont candidates. Aquaculture International, 25(1), 485-498. https://doi.org/10.1007/s10499-016-0045-6

Bachere, E., 2000. Shrimp immunity and disease control - Introduction. Aquaculture, 191(1-3), 3-11. https://doi.org/10.1016/S0044-8486(00)00413-0

Bahrndorff, S., de Jonge, N., Skovgard, H., and Nielsen, J.L., 2017. Bacterial Communities Associated with Houseflies (Musca domestica L.) Sampled within and between Farms. PLoS One, 12(1). https://doi.org/10.1371/journal.pone.0169753

Barszcz, M., Taciak, M., and Skomial, J., 2016. The effects of inulin, dried Jerusalem artichoke tuber and a multispecies probiotic preparation on microbiota ecology and immune status of the large intestine in young pigs. Archives of Animal Nutrition, 70(4), 278-292.

https://doi.org/10.1080/1745039X.2016.1184368

Boulares, M., Mankai, M., Sadok, S., and Hassouna, M., 2017. Anti-Listerial inhibitory lactic acid bacteria in fresh farmed sea bass (Dicentrarchus labrax) fillets during storage at 4 degrees $\mathrm{C}$ under vacuum-packed conditions. Journal of Food Safety, 37(3).

Caporaso, J.G., Kuczynski, J., Stombaugh, J., Bittinger, K., Bushman, F.D., Costello, E.K., Fierer, N., Pena, A.G., Goodrich, J.K., Gordon, J.I., Huttley, G.A., Kelley, S.T., Knights, D., Koenig, J.E., Ley, R.E., Lozupone, C.A., McDonald, D., Muegge, B.D., Pirrung, M., Reeder, J., Sevinsky, J.R., Tumbaugh, P.J., Walters, W.A., Widmann, J., Yatsunenko, T., Zaneveld, J., and Knight, R., 2010. QIIME allows analysis of high-throughput community sequencing data. Nature Methods, 7(5), 335-336. https://doi.org/10.1038/nmeth.f.303

Chalova, V.I., Lingbeck, J.M., Kwon, Y.M., and Ricke, S.C., 2008. Extracellular antimutagenic activities of selected probiotic Bifidobacterium and Lactobacillus spp. as a function of growth phase. Journal of Environmental Science and Health Part B-Pesticides Food Contaminants and Agricultural Wastes, 43(2), 193-198. https://doi.org/10.1080/03601230701795262

Cho, S., Hwang, O., and Park, S., 2015. Effect of dietary protein levels on composition of odorous compounds and bacterial ecology in pig manure. Asian-Australasian Journal of Animal Sciences, 28(9), 1362-1370.

Dige, I., Nyengaard, J.R., Kilian, M., and Nyvad, B., 2009. Application of stereological principles for quantification of bacteria in intact dental biofilms. Oral Microbiology and Immunology, 24(1), 69-75. https://doi.org/10.1111/j.1399-302x.2008.00482.x

Egan, A.F., 1983. Lactic-acid bacteria of meat and meat-products. Antonie Van Leeuwenhoek Journal of Microbiology, 49(3), 327-336.

Gatesoupe, F.J., 2008. Updating the importance of lactic acid bacteria in fish farming: Natural occurrence and probiotic treatments. Journal of Molecular Microbiology and Biotechnology, 14(1-3), 107-114. https://doi.org/10.1159/000106089

Ghanbari, M., Jami, M., Domig, K.J., and Kneifel, W., 2013. Seafood biopreservation by lactic acid bacteria - A review. Lwt-Food Science and Technology, 54(2), 315-324. doi:10.1016/j.lwt.2013.05.039 https://doi.org/10.1016/j.lwt.2013.05.039

Godoy, F.A., Miranda, C.D., Wittwer, G.D., Aranda, C.P., and Calderon, R., 2015. High variability of levels of Aliivibrio and lactic acid bacteria in the intestinal microbiota of farmed Atlantic salmon Salmo salar L. Annals of Microbiology, 65(4), 2343-2353. https://doi.org/ 10.1007/s13213-015-1076-3

Gorham, J.B., Kang, S., Williams, B.A., Grant, L.J., McSweeney, C.S., Gidley, M.J., and Mikkelsen, D., 2017. Addition of arabinoxylan and mixed linkage glucans in porcine diets affects the large intestinal bacterial populations. European Journal of Nutrition, 56(6), 2193-2206. https://doi.org/10.1007/s00394-016-1263-4 
Gungor, O.E., Kirzioglu, Z., Dincer, E., and Kivanc, M., 2013. Who will win the race in childrens' oral cavities? Streptococcus mutans or beneficial lactic acid bacteria? Beneficial Microbes, 4(3), 237-245. https://doi.org/10.3920/BM2012.0055

Guo, Y., Huang, Z.P., Liu, C.Q., Qi, L., Sheng, Y., and Zou, D.J., 2017. Modulation of the gut microbiome: a systematic review of the effect of bariatric surgery. European journal of endocrinology. https://doi.org/10.1530/EJE-17-0403

Hai, N.V., 2015. The use of probiotics in aquaculture. Journal of Applied Microbiology, 119(4), 917-935. https://www.dx.doi.org/10.1016/j.fsi.2015.05.026

Hatziioanou, D., Gherghisan-Filip, C., Saalbach, G., Horn, N., Wegmann, U., Duncan, S.H., Flint, H.J., Mayer, M.J., and Narbad, A., 2017. Discovery of a novel lantibiotic nisin O from Blautia obeum A2-162, isolated from the human gastrointestinal tract. Microbiology (Reading, England), 163(9), 1292-1305. https://doi.org/10.1099/mic.0.000515

Jeong, J.H., Lee, C.Y., and Chung, D.K., 2016. Probiotic lactic acid bacteria and skin health. Critical Reviews in Food Science and Nutrition, 56(14), 2331-2337. https://doi.org/10.1080/10408398.2013.834874

Kanmani, P., Satishkumar, R., Yuvaraj, N., Paari, K.A., Pattukumar, V., and Arul, V., 2011. The role of environmental factors and medium composition on bacteriocin production by an aquaculture probiotic Enterococcus faecium MC13 isolated from fish intestine. Korean Journal of Chemical Engineering, 28(3), 860-866. https://doi.org/10.1007/s11814-010-0443-9

Kobierecka, P.A., Wyszynska, A.K., Aleksandrzak-Piekarczyk, T., Kuczkowski, M., Tuzimek, A., Piotrowska, W., Gorecki, A., Adamska, I., Wieliczko, A., Bardowski, J., and JagusztynKrynicka, E.K., 2017. In vitro characteristics of Lactobacillus spp. strains isolated from the chicken digestive tract and their role in the inhibition of Campylobacter colonization. MicrobiologyOpen.

Lavari, L., Burns, P., Paez, R., Reinheimer, J., and Vinderola, G., 2017. Study of the effects of spray drying in whey-starch on the probiotic capacity of Lactobacillus rhamnosus 64 in the gut of mice. Journal of Applied Microbiology, 123(4), 992-1002.

Lee, B.H., Lo, Y.H., and Pan, T.M., 2013. Anti-obesity activity activity of Lactobacillus fermented soy milk products. Journal of Functional Foods, 5(2), 905-913. https://doi.org/10.1016/j.jff.2013.01.040

Maeda, M., Shibata, A., Biswas, G., Korenaga, H., Kono, T., Itami, T., and Sakai, M., 2014. Isolation of lactic acid bacteria from kuruma shrimp (Marsupenaeus japonicus) intestine and assessment of immunomodulatory role of a selected strain as probiotic. Marine Biotechnology, 16(2), 181-192. doi:10.1007/s10126-013-9532-1 https://doi.org/10.1007/s10126-013-9532-1

Matsumoto, S., Hara, T., Nagaoka, M., Mike, A., Mitsuyama, K., Sako, T., Yamamoto, M., Kado, S., and Takada, T., 2009. A component of polysaccharide peptidoglycan complex on Lactobacillus induced an improvement of murine model of inflammatory bowel disease and colitis-associated cancer. Immunology, 128(1), e170-e180. https://www.dx.doi.org/10.1111/j.1365-2567.2008.02942.x
Matteotti, C., Haubruge, E., Thonart, P., Francis, F., De Pauw, E., Portetelle, D., and Vandenbol, M., 2011. Characterization of a new beta-glucosidase/beta-xylosidase from the gut microbiota of the termite (Reticulitermes santonensis). FEMS Microbiology Letters, 314(2), 147-157.

https://doi.org/10.1111/j.1574-6968.2010.02161.x

Newaj-Fyzul, A., Adesiyun, A.A., Mutani, A., Ramsubhag, A., Brunt, J., and Austin, B., 2007. Bacillus subtilis AB1 controls Aeromonas infection in rainbow trout (Oncorhynchus mykiss, Walbaum). Journal of Applied Microbiology, 103(5), 1699-1706. https://doi.org/10.1111/j.1365-2672.2007.03402.x

Nikoskelainen, S., Ouwehand, A.C., Bylund, G., Salminen, S., and Lilius, E.M., 2003. Immune enhancement in rainbow trout (Oncorhynchus mykiss) by potential probiotic bacteria (Lactobacillus rhamnosus). Fish \& Shellfish Immunology, 15(5), 443-452. https://doi.org/10.1016/S1050-4648(03)00023-8

Park, D.Y., Ahn, Y.T., Park, S.H., Huh, C.S., Yoo, S.R., Yu, R., Sung, M.K., McGregor, R.A., and Choi, M.S., 2013. Supplementation of Lactobacillus curvatus HY7601 and Lactobacillus plantarum KY1032 in diet-induced obese mice is associated with gut microbial changes and reduction in obesity. PLoS One, 8(3). https://doi.org/10.1371/journal.pone.0059470

Pattukumar, V., Kanmani, P., Kumar, R.S., Yuvaraj, N., Paari, A., and Arul, V., 2014. Enhancement of innate immune system, survival and yield in Penaeus monodon reared in ponds using Streptococcus phocae PI80. Aquaculture Nutrition, 20(5), 505-513.

Pikuta, E.V., Hoover, R.B., Bei, A.K., Marsic, D., Whitman, W.B., Krader, P.E., and Tang, J., 2006. Trichococcus patagoniensis sp nov., a facultative anaerobe that grows at -5 degrees $C$, isolated from penguin guano in Chilean Patagonia. International Journal of Systematic and Evolutionary Microbiology, 56, 2055-2062. https://doi.org/10.1099/ijs.0.64225-0

Pothakos, V., Snauwaert, C., De Vos, P., Huys, G., and Devlieghere, F., 2014. Psychrotrophic lactic acid bacterium (LAB) contamination: a spoilage problem for cold-stored and packaged food products. Communications in Agricultural and Applied Biological Sciences, 79(1), 137-142.

Rahman, N.M.A., Fu, H.T., Sun, S.M., Qiao, H., Jin, S., Bai, H.K., Zhang, W.Y., Liang, G.X., Gong, Y.S., Xiong, Y.W., and $\mathrm{Wu}, \mathrm{Y} ., 2016$. Molecular cloning and expression pattern of oriental river prawn (Macrobrachium nipponense) nitric oxide synthase. Genetics and Molecular Research, 15(3).

Rajoka, M.S.R., Shi, J., Zhu, J., Shao, D., Huang, Q., Yang, H., and Jin, M., 2017. Capacity of lactic acid bacteria in immunity enhancement and cancer prevention. Applied Microbiology and Biotechnology, 101(1), 35-45.

Ringo, E., Bendiksen, H.R., Gausen, S.J., Sundsfjord, A., and Olsen, R. E., 1998. The effect of dietary fatty acids on lactic acid bacteria associated with the epithelial mucosa and from faecalia of Arctic charr, Salvelinus alpinus (L.). Journal of Applied Microbiology, 85(5), 855-864. https://doi.org/10.1046/j.1365-2672.1998.00595.x

Ringo, E., and Gatesoupe, F.J., 1998. Lactic acid bacteria in fish: a review. Aquaculture, 160(3-4), 177-203. https://doi.org/10.1016/S0044-8486(97)00299-8 
Ringo, E., Lovmo, L., Kristiansen, M., Bakken, Y., Salinas, I., Myklebust, R., Olsen, R.E., and Mayhew, T.M., 2010. Lactic acid bacteria vs. pathogens in the gastrointestinal tract of fish: a review. Aquaculture Research, 41(4), 451-467. https://doi.org/10.1111/j.1365-2109.2009.02339.x

Schloss, P.D., Westcott, S.L., Ryabin, T., Hall, J.R., Hartmann, M., Hollister, E.B., Lesniewski, R.A., Oakley, B.B., Parks, D.H., and Robinson, C.J., 2009. Introducing mothur: open-source, platform-independent, community-supported software for describing and comparing microbial communities. Applied and Environmental Microbiology, 75(23), 7537-7541. https://doi.org/10.1128/AEM.01541-09

Stolaki, M., De Vos, W.M., Kleerebezem, M., and Zoetendal, E.G., 2012. Lactic Acid Bacteria in the Gut.

Suzer, C., Coban, D., Kamaci, H.O., Saka, S., Firat, K., Otgucuoglu, O., and Kucuksari, H., 2008. Lactobacillus spp. bacteria as probiotics in gilthead sea bream (Sparus aurata, L.) larvae: Effects on growth performance and digestive enzyme activities. Aquaculture, 280(1-4), 140-145. https://doi.org/10.1016/j.aquaculture.2008.04.020

Tapia-Paniagua, S.T., Diaz-Rosales, P., Leon-Rubio, J.M., Garcia de La Banda, I., Lobo, C., Alarcon, F.J., Chabrillon, M., Rosas-Ledesma, P., Varela, J.L., Ruiz-Jarabo, I., Arijo, S., Esteban, M.A., Martinez-Manzanares, E., Mancera, J.M., Balebona, M.C., and Morinigo, M.A., 2012. Use of the probiotic Shewanella putrefaciens Pdp11 on the culture of Senegalese sole (Solea senegalensis, Kaup 1858) and gilthead seabream (Sparus aurata L.). Aquaculture International, 20(6), 1025-1039. https://doi.org/10.1007/s10499-012-9509-5

Tzeng, T.D., Pao, Y.Y., Chen, P.C., Weng, F.C.H., Jean, W.D., and Wang, D., 2015. Effects of host phylogeny and habitats on gut microbiomes of oriental river prawn (Macrobrachium nipponense). PLoS One, 10(7). https://www.dx.doi.org/10.1371/journal.pone.0132860

Van Hai, N., Fotedar, R., and Buller, N., 2007. Selection of probiotics by various inhibition test methods for use in the culture of western king prawns, Penaeus latisulcatus (Kishinouye).
Aquaculture, 272(1-4), 231-239.

https://doi.org/10.1016/j.aquaculture.2007.07.223

Vasquez, A., Forsgren, E., Fries, I., Paxton, R.J., Flaberg, E., Szekely, L., and Olofsson, T.C., 2012. Symbionts as major modulators of insect health: lactic acid bacteria and honeybees. PLoS One, 7(3). https://doi.org/10.1371/journal.pone.0033188

Vazquez, L., Florez, A.B., Guadamuro, L., and Mayo, B., 2017. Effect of soy isoflavones on growth of representative bacterial species from the human gut. Nutrients, 9(7). https://doi.org/10.3390/nu9070727

Von Wright, A., and Axelsson, L., 2012. Lactic Acid Bacteria: An Introduction. https://doi.org/10.1016/S0044-8486(97)00299-8

Wang, Q., Garrity, G.M., Tiedje, J.M., and Cole, J.R., 2007. Naive Bayesian classifier for rapid assignment of rRNA sequences into the new bacterial taxonomy. Applied and Environmental Microbiology, 73(16), 5261-5267. https://doi.org/10.1128/AEM.00062-07

Wu, X., Zhang, H., Chen, J., Shang, S., Yan, J., Chen, Y., Tang, X., and Zhang, H., 2017. Analysis and comparison of the wolf microbiome under different environmental factors using three different data of Next Generation Sequencing. Scientific Reports, 7.

Xu, J., Chen, X., Yu, S., Su, Y., and Zhu, W., 2016. Effects of early intervention with sodium butyrate on gut microbiota and the expression of inflammatory cytokines in neonatal piglets. PLos One, 11(9). https://doi.org/10.1371/journal.pone.0162461

Yu, G., and Zhou, H., 2005. Current research status of fish immunostimulants. Journal of Jilin Agricultural University, 27(3), 344-349.

Zheng, X., Tang, J., Ren, G., and Wang, Y., 2017. The effect of four microbial products on production performance and water quality in integrated culture of freshwater pearl mussel and fishes. Aquaculture Research, 48(9), 4897-4909. https://www. dx.doi.org/10.1111/are.13309 